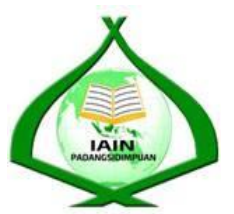

ENGLISH EDUCATION

English Journal for Teaching and Learning

Vol. 07 No. 01 June 2019 page 29 - 44

http://jurnal.iain-padangsidimpuan.ac.id/index.php/EEJ

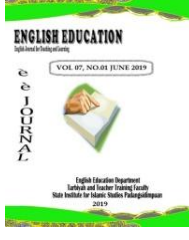

\title{
Contextual Guessing Technique in Reading
}

\section{Syamsiah Depalina Siregar*}

Universitas Muhammadiyah Tapanuli Selatan (UMTS), Padangsidimpuan

Email : syamsiah.depalina@um-tapsel.ac.id

Abstract This research aimed to know whether students' reading comprehension can improve with use Contextual Guessing Technique and to know how the implementation of this method in reading class. This research used action research classroom. The finding of the research was the students more enthusiast in answering the reading's question. The test result came from first cycle and second cycle. It showed improvement. The conclusion was the students need learning technique relate with their learning level. Contextual Guessing Technique is one of the appropriate techniques in reading class for senior high students. This case proved by the students more motivated and spirit in learning English especially in reading. Therefore the students got good score.

Keywords: Contextual Guessing Technique; reading comprehension; action research; reading strategies; students' reading level.

Abstrak Penelitian ini bertujuan untuk mengetahui apakah pemahaman membaca siswa dapat ditingkatkan dengan menggunakan Contextual Guessing Technique dan untuk mengetahui bagaimana penerapan metode ini dapat meningkatkan pemahaman siswa dalam membaca bahasa Inggris. Peneliti menggunakan Penelitian Tindakan Kelas (PTK) sebagai metode penelitiannya. Temuan penelitian adalah siswa lebih antusias dalam menjawab soal reading. Hasil tes dari siklus pertama dan siklus kedua menunjukkan peningkatan. Adapun kesimpulan dari penelitian ini adalah siswa membutuhkan teknik pembelajaran yang sesuai dengan level mereka, Contextual Guessing Technique adalah salah satu teknik pembelajaran untuk reading yang sesuai, hal ini diperoleh dari hasil penelitian yang telah dilakukan, siwa lebih termotivasi, siswa lebih bersemangat dalam belajar bahasa Inggris sehingga hasil nya pun lebih bagus.

Kata Kunci: Contextual Guessing Technique; reading comprehension; action research; reading strategies; students' reading level.

*Corresponding Author: syamsiah.depalina@um-tapsel.ac.id 


\section{INTRODUCTION}

In learning English, students are expected to get some messages from their text book. The students have facing with English from the fifth class in elementary school until now in tenth class of senior high school, it implies that after studying the language for five years, it is expected that students will be able to comprehend a reading text as well as possible. In contrary, they have many problems with English, such as difficult words, their less ability in understanding the context, and low mastery of translation.

Among four language skill, Reading is one of way to enhance science and information. Reading is an active activity. By reading, students also can master many words and can learn types and models of sentence more. Students can improve their ability to catch concept and to comprehend what is read line by line. By reading, students will be able to enhance their concept if students are able to increase their ability in reading comprehension.

The skill of reading comprehension is students' provisions and key of the success in running the process of education. The majority, the science achievement is done by students through reading activity. The science that is gained by the students is not only from the process of teaching-learning in school but also through the reading activity in daily life. Therefore, the technique of reading comprehension becomes the important part in mastering and in enhancing the students' knowledge.

In the interview with some students in a senior high school, they said that they facing up difficulties in analyzing the implicit and explicit information of the text. Besides, many students have not enthusiastic in reading class. The teacher only uses monotonous technique namely, conventional technique. In the reading class, the teacher presents a subject in the text book and asks students to read whether silently or loudly, and then the students have to answer the questions based on the text book. Consequently, the reading lesson becomes monotonous and bored, they showed bad attitudes. Finally, the students are not able to get good scores in their reading class.

In improving students' reading comprehension, the researcher introduces contextual guessing technique. It can be applied to find out what the students 
know, what they are thinking, stimulate them to think, and change their thinking. The students can guess the information of reading text to find out some interesting information. Brown defines By contextual guessing technique readers can identify important words in reading and can in fact make semantic predictions about their relationship to one another. ${ }^{1}$ It means that using contextual guessing technique can be made as the way of teaching to get some information from reading texts. Before students read, the teacher asks the students to find prior knowledge, make predictions, and wonder about big ideas that are not answered in the text. Contextual guessing technique can be a focusing and refining device for expanding vocabulary and for developing all level of comprehension, including critical and creative reading. Therefore, using this technique will help the students to enlarge their thinking. In other word, contextual guessing technique makes students to be good reader who can comprehend reading text easily. Therefore, the researcher wants to see the effect of using Contextual Guessing Technique in improving students' reading comprehension in senior high school level.

Before come to the definition of reading comprehension, firstly the writer would like to present the definition of comprehension itself. Many expert give their statement about that, the one is Smith says Comprehension is receiving relevant answers to those questions. ${ }^{2}$ In this word, comprehension doesn't just happen, it requires effort. Readers must intentionally and purposefully work to create meaning from what they read. According to Grover argues that reading comprehension is a dynamic interactive process of constructing meaning by combining the reader's existing knowledge with the text information within the context of the reading situation. ${ }^{3}$ it means that reading comprehension as the way to refining the idea of the meaning on the text, and it can be through by interaction between reader and text.

${ }^{1}$ Brown, H. D, Language Assessment. Principles and Classroom Practices. (New York: Longman. Pearson Education, 2003), p. 308-309

2 Smith, Frank, "Understanding Reading a Psycholinguistic Analysis of Reading and Learning to Read", (London: Mahwah,2004) , p. 30

${ }^{3}$ Grover, J, A Guided to Curriculum Planning in Reading. (Wisconsin Department of Public Instruction,2004), p. 6 
Furthermore, Pearson et al said that reading comprehension is a process in which the reader constructs meaning using as the building materials the information on the printed page and the knowledge stored in the readers head. ${ }^{4}$ It means that, reading comprehension is a result of the difficult interaction between the text and reader based on the context.

In addition, O'Malley said that reading comprehension depends heavily on knowledge about the worlds as well as on knowledge of language and print. Readers construct new knowledge from the interaction between text and their own background knowledge. ${ }^{5}$ Next, Brown wrote that reading comprehension is primary a matter of develops appropriate, efficient comprehension strategies. ${ }^{6}$ And a lot of processes interact with text features and theses are interactive as far as they are widely accepted models of fluent reading.

The last, Smith argued that reading comprehension is the meaning of the word reading in all these senses on everything that is going on-not just on what is being read, but on why a particular reader. ${ }^{7}$ In this quotation, the reader must be able to understand, to interpret and to select information from text book.

From the explanation, the writer concludes that reading comprehension is one way of finding information from the text, and it is also made as a source of information. Reading comprehension is included a some of difficult subjects for students' skill in explaining the text after reading and answering the question based on the text, defining vocabulary based on the context, and finding knowledge about certain vocabulary.

\section{Strategies of Reading Comprehension}

Brown wrote the strategies of reading comprehension, such as: ${ }^{8}$

1. Identify the purposes in reading

How many times have the reader been told to read something yet you do not know? Why the reader are being asked to read it? The reader did not only a mediocre of retaining what you read and perhaps was rather slow in the process.

4 Pearson David, Barbara M. Taylor (2002) Teaching Reading. (Laurence Erlbaum Associates. Inc. Publisher. London,2002), p. 423

${ }^{5}$ O'Malley, J, Authentic Assesment for English Language Learners. (Addition-Wesley Publishing Company, 1996), p.94

${ }^{6}$ Brown, Op.Cit., p.306

7 Smith, Frank, Op.Cit., p.180

${ }^{8}$ Brown, Op.Cit., p.306 
2. Use grapheme rules and patterns to aid in bottom-up decoding (especially for beginning level learners)

At the beginning levels of leaning English, one of the difficulties students encounter in learning to read is making correspondences between spoken and written English. In many cases, learners have become acquainted with oral language and have some difficulty learning English spelling conversation. Considers how provider hints and pointers on such patterns as these might

- Shorts "vowel" sounds in VC patterns (bat, him, legs)

- Long "vowel" sounds in VCe final silent e (late, time)

3. Use efficient silent reading technique for relatively rapid comprehension

If you are teaching beginning level students, this particular level strategy will not apply because they are still struggling with the control of a limited vocabulary and grammatical patterns.

4. Skim the text of Main Idea

Perhaps the two most valuable reading strategies for reading strategies for learners (as well as native speakers) are skimming and scanning.

\section{Purposes of Reading Comprehension}

The aims instruction in beginning reading is to make the students be independent reader. There are many purposes for reading. According to Williams purpose of reading is classified into: 1 . getting information from the text, 2. getting specific information from the text, and 3. reading for pleasure or for interest. Dubin et al describe reading purpose as follow: 1. reading for facts and opinions, 2. reading for ideas and view points, 3. reading for learn, and 4. reading for discovery.

From the above explanations, it can be concluded that reading comprehension is the process by which a person understanding the meaning of written language clearly in order to extracting information from the text that writer and the information is intended to answer the specific questions that the readers are asking or grasping the pattern from the written representation quickly without analysis of that symbols represent what sound.

\section{Levels of Reading Comprehension}

Levels of comprehension can tell us about how far the students comprehend about reading material and which level has been gained. Burns state 
there are four levels of reading comprehension that must be gained in reading comprehension. They are:

\section{Literal Comprehension}

Literal comprehension which involve acquiring information that is stated directly. The basic of literal comprehension is recognizing stated main idea, detailed cause effect and sequence. It is also prerequisite for higher level understanding. Recognizing stated main ideas, details, causes, and sequence is the basis of literal comprehension, and through understanding of vocabulary, sentence meaning, and paragraph meaning is important.

\section{Interpretative Comprehension}

Interpretative Comprehension, involves reading between the lines or making inferences. It is the process of deriving ideas that are implied rather than directly stated. This level includes inferring main ideas of passages in which the main ideas are not directly stated. Cause and effect relationship when they are not stated directly, reference of pronouns, reference of adverbs, omitted words, detecting mood, detecting the author's purposes in writing, and drawing conclusions.

\section{Critical Comprehension}

Critical comprehension, involves evaluating written material, comparing the material with known standards and drawing conclusions about their accurately, appropriateness, and timeless. Critical comprehension refers to the skill to make judgment about ideas and information a writer offers. Competent reader will measure with holding judgment until confirmation is reached.

4. Creative Comprehension

Creative comprehension, involves going beyond the material presented by the author. It requires readers to think as they read, just as critical reading does, and it also requires them to use their imagination.

\section{Process of Reading Comprehension}

The learning in reading comprehension is known concept bottom-up and top-down. According to Goodman says that the nucleus of this top-down is the reader begins process of comprehension on the text from the higher structure. The reader begins the steps of reading by reading predictions and hypothesis that relates with what possibly existing in the reading, has knowledge as capital 
about the content and the language that owned. For assisting comprehension by using this theory, the reader uses strategy based on the using of addition direction such as the competence in language that owned. Then, Brown says that there are processes in reading comprehension. They are bottom-up and topdown. Brown explains bottom-up as follow: ${ }^{9}$

In bottom-up processing, readers must first recognize a multiplicity of linguistic signal (letters, morphemes, syllables, words, phrase, grammatical clues, discourse markers) and use their linguistic data-processing mechanism to impose some sort of order on these signals.

(Brown, 2000:299)

Based on the explanation above, the main principle of bottom-up, reading comprehension relies on linguistic signs to interpret the meaning in a text. The reader will pay attention word by word accurately to comprehend the text. Further, based on theory top-down above, it can be concluded that knowledge, experience, and intelligence of reader required as basic in comprehending the reading.

\section{The Contextual Guessing Technique}

According to Patel et al argues that contextual guessing technique is a technique to guess the meaning of the word is something that is important for a the English learners because it can improve the ability to think and the ability to connect to students because they enable the current skills guess the meaning of the word. ${ }^{10}$ In the other words, their curiosity the meaning of the word encourages them to connect the word with the context of the sentence. In the end, when they managed to guess correctly, they will more confident to try this way then on the other.

In addition, Clarke \& Nation (1980: 217) implied that To guess a meaning the reader must consider and interpret the available evidence, predict what should occur, and seek confirmation of the prediction. Thus developing the skill of guessing meanings is in many ways developing the skill of reading. In these

\footnotetext{
${ }^{9}$ Brown, Op.Cit., p.299

${ }^{10}$ Patel et al, Guessing Words-in-Context Strategies Used by Beginning and UpperIntermediate Learners. (Unpublished MA dissertation, Bilkent University, Ankara, 2008), p.88
} 
word, To develop reading efficiency guessing from context is useful "The ability to guess the meaning of a word without referring to a dictionary saves time and allows the reader to continue reading without interruption. In this way it increases reading efficiency. At some stage it is worth giving learners practice in deciding which ungues sable words should be looked up in the dictionary and which should be ignored.

Meanwhile, Scott Thornbury (2002:148) argued that guessing from context is probably one of the most useful skills learners can acquire and apply both inside and outside the classroom. What's more, it seems to be one that can be taught and implemented relatively easily. It is also one that we all already useperhaps unconsciously-when reading and listening in our mother tongue. Stresses the importance of learning in context. He states that for vocabulary building purposes, texts - whether spoken or written - have enormous advantages over learning words from lists. For a start, the fact that words are in context increases the chances of learners appreciating not only their meaning but their typical environments, such as their associated collocations or grammatical structures. Moreover, it is likely that the text will display topically connected sets of words or lexical fields. Research evidence suggests that words loosely connected by topic may be easier to learn than more tightly connected lexical sets.

In addition Haastrup explained that contextual inference or contextual guessing is defined as an important strategy in the absence of dictionary or human assistance and it " entails guessing the meaning of target word based on interpretation of its immediate co-text with or without reference to knowledge of the world. Those states above explained how important and how effective the applying of Contextual Guessing Technique in teaching English. Students become actively involved in the discovery of new word meanings and learn useful reading behaviors from one another.

Furthermore, Askari et al studied on the effect of guessing vocabulary on reading authentic texts. Guessing from the context is one of the most useful skills 
learners can acquire and apply inside and outside classroom. Mikulecky et al states that this technique is effective because: 11

1) Fast and the reader is not disturbed read activity.

2) Helps improve understanding in reading because the reader remains focus on reading the contents being read.

3) Helping to build vocabulary for tend to remember words predictable.

4) Make more readers enjoy reading because it does not need stop intermittently.

Contextual guessing is the most important skill used by most readers in attacking new words ${ }^{12}$. It is closely related to comprehension and this is one of the most practical skills students learn. Context clues have several uses in reading ${ }^{13}$. Linear with explanation above it can be said that context clues can function only if the material is suited to the reader in terms of difficulty and familiarity or interest. If the context is too involved, or if there are too many unknown words, context is of little value. When the material deals with unfamiliar concepts or is dry and dull to the reader, he is not likely to be able to develop a continuous line of thought suitable for anticipating an unknown word. All reading materials, therefore, should be chosen with these criteria in mind:

a. Reading materials should be of interest to the reader.

b. Concepts developed in the material should be in line with the reader's experience background.

c. There should be no more than one unfamiliar word to among 20 conceptive words in materials used for contextual guessing training.

d. Upper-grading reading materials should include pictures, graphs, charts and tables.

e. Sentence structure should be appropriate for the achievement level and language maturity of the students.

The procedures for developing abilities in contextual guessing can be incorporated in class reading presentations or special exercises. Before we go further analyzing contextual guessing we must consider a few preliminary

11 Mikulecky, B S. and Jeffries, L. (1996). More Reading Power. (Addison Wesley Publishing Company, 1996 Inc. Developing teachers.com. Available at: www.developing teachers.com. Accessed on Saturday, January 02, 2019.), p.49

12 ( Çetinavcı, B. M. (2014). Contextual Factors in Guessing Word Meaning from Context in a Foreign Language. Procedia - Social and Behavioral Sciences, 116(1999), 26702674. https://doi.org/10.1016/j.sbspro.2014.01.633).

13 Qian, T.(2005). On Contextual Guessing in Reading Comprehension. US-China Foreign Language. Available at: www.linguist.org . Accessed on Saturday, January 02, 2019. 
questions concerning this skill. These questions pertain to the usefulness and to the trainability of the guessing skill. As to the usefulness, the favorable effect of the guessing skill on reading speed and text comprehension can be well noted. It is self-evident that a reader who is not able to use context adequately will have to refer to the dictionary continually and in many cases will not be able to choose the correct alternative. With respect to the trainability of the skill we may refer to an investigation to a varied series of experiments carried out in an English reading class in our university. All the experiments require subjects (three different levels) to try to guess the meaning of unknown words (limited in number) or to fill in blanks in their foreign language texts. Then they were asked to verbalize their thought processes. An analysis was made by contrasting successful and unsuccessful actions of different subjects with respect to the same unknown words or blanks.

Analysis of the experiments indicated that different subjects can act on different linguistic levels. The subjects were found to be acting on a syntactic level when trying to find out the grammatical structure of a sentence. They were acting on a semantic level when exploring the immediate or wider context of the unknown word or blank in order to find its meaning. Subjects were acting on a lexical level when they inspected the word form in order to derive its meaning. Sometimes, though not always, they were acting on a stylistic level when they tried to appreciate the stylistic usage of a word. These analyses also indicated that guessing skill is trainable.

From the explanation above, the researcher concluded Contextual guessing technique is a technique to find the meaning of an unknown word without a dictionary. This technique can encourage the students to make intelligent guesses about word meaning. Besides that, this will help the students read faster because the students stay focused on the general sense of what they read.

\section{The Basic Technique of Contextual Guessing}

Irnanda wrote the four basic technique of CG are as follows:

1. Predicting, It means prediction of general idea of the text from the title or the heading. 
2. Synonyms, Hancock defines a synonym are two or more words that have meaning same or similar. Time an author uses a term difficult, they often use also a synonym for the word to make meaning becomes clearer.

3. Antonyms or Contrast, Antonym is a word that has the opposite meaning. A piece placed opposite meaning in a context will provide contrast clue to the meaning of the word not known. Conjunctions such as 'although', 'but' and 'but' be this contrasting relationship signals.

4. Example, Another way to give instructions to readers in finding the meaning of difficult words is to use an example. An author can provide one or more example. These examples are not the same with synonyms. The words indicate like, 'Reviews such as',' Including ', and' Consists of '. Punctuation such as a colon (:) and a dash (-) can also be a clue granting sample / example. Example: The river was full of noxious materials Reviews such as cleaning agents from factories and pesticides from nearby farms.

5. General sense of Passage

According Dycus (1997: 2) context is not something absolute no in the text, but sometimes created itself by the reader. In other words, readers have contributed in construct the meaning of the word in the context. example: The cat springs on the rat.

The word 'spring' in the above sentence can guess its meaning because we can construct meaning based on common sense of the sentence. Cats usually, in real-life context, do something which hurt the mice. So that, we have narrow the meaning of spring here; that meaning must be an action that is negative. Some experts consider the type This instruction manual that comes from readers so that they breaks it into knowledge early or prior knowledge.

\section{METHOD}

The research method used in this research was action research. It consisted 2 cycles. Every cycle has two meetings with four steps. They are planning, acting, observing and reflecting. The subject of the research was students in grade $X$ senior high school. To conduct such research, this method has two main objectives: first, to describe, explore, and explain the use Contextual Guessing Technique in students' reading comprehension; second, to know is it can improve students' reading comprehension. The data of this study were obtained 
from several instruments, namely class observations, questionnaire, documentation and students' reading test which were then analyzed using reading assessment criteria taken from Rose (2007, as cited by Emilia, 2011, p. 151). In the end, all data were categorized into some research questions to obtain the results of this study.

\section{RESULT AND DISCUSSION CYCLE I}

The data got from analyzing the result of the action in post test, the researcher concluded that the student' reading comprehension was improved. To be detail the students passed the third of indicators, the researcher would be explain: 1) The students who passed Identification Topic (IT) there are 21 students. 2) The students who passed Main Idea (MI) there are Students and 3) The students who passed Supporting Detail (SD) there are 12 in first cycle. It was shown by the average of posttest, which is higher than the average of pretest. The researcher also calculates the standardized of minimum score (KKM) in score 75. The result of post-test shows that students who complete this standardized is more than in pre-test, in pre-test there is only 13 students who has the score more than KKM and in post-test only 23 students who have the score more than KKM. It was shown the target $75 \%$ not be able. From the result researcher thinks that necessary to carry out cycle 2 . In other hand, the researcher needed to explain the material in detail in order to make the students understand well. She must guide the students to discuss and present the material in front of the class. Besides, the students must be more active to ask the teacher when they did not understand about the lesson. The researcher will use the same technique to teach reading comprehension with the different topic for the next cycle to get better result.

\section{Cycle II}

In the next cycle, it was needed to overcome motivation of students to comprehend the text. Re-planning of the Contextual Guessing Technique in the first cycle after second cycle, which resolved in the second technique, clearly will be figured in the following table. 
Table 1

The First and second cycle Problems and Resolutions

\begin{tabular}{|c|c|}
\hline Problems in the First & The Solution \\
\hline $\begin{array}{l}\text { 1. Were not bravery to read the } \\
\text { text }\end{array}$ & $\begin{array}{l}\text { 1. Teacher explains them that they have } \\
\text { good talent must be showed out }\end{array}$ \\
\hline 2. Afraid to do mistake & $\begin{array}{l}\text { 2. Teacher understands them to try and } \\
\text { practice be optimistic }\end{array}$ \\
\hline 3. High anxiety & 3. Teacher suggests them to be bravery \\
\hline $\begin{array}{l}\text { 4. Lack of self-confidence } \\
\text { when the teacher older to } \\
\text { read. }\end{array}$ & $\begin{array}{l}\text { 4. Teacher motivates them to build the } \\
\text { self-confidence be bravery readers. }\end{array}$ \\
\hline
\end{tabular}

Generally, there were significant developments of the acting phase in second cycle. From the observation note that has been taken by the researcher that the researcher performance in teaching English has implemented the method a bit better than first cycle. The researcher used the time with effectiveness and also management class was good enough. The classroom situation controlling also can be handle by researcher when students work with their task. Overall, students looked more enthusiastic in doing activity than before. The students can answer the question.

This study investigated the increase reading comprehension with Contextual Guessing Technique at the grade X senior high school. The results in present study are very similar to each other. The researcher stated that guessing scores are very different from poor context to rich context as remarked above with saying pre-teaching was beneficial and contributing for the students. Although the skill of guessing word meanings from context is widely acknowledged as a useful skill there has been little research in this area and very little useful guidance for teachers or learners. While searching for the research studies that were similar to ours we benefited from some of them. In terms of goal, the most similar one was "Contextual factors in guessing word meaning from context in a foreign language" study conducted by Cetinavci. She examined some factors that cause impairment of reading comprehension when acquainted with unknown words. Different from the 
researcher procedure, Cetinavci. divided the sentences into two different groups in terms of contextual richness. Her finding showed that rich context has enabled the language learners to guess word meaning from the context correctly is consistent with the other findings of previous studies in literature. When the context is rich it contains much more clues and the learners notice them but also guess the unknown words' meaning easily. In the pre-test, the reading texts contained more clues and they were longer than the ones in post-test. According to observation the reason why the participants' scores were not so low in pre-test is about the text was longer and richer in terms of context. When language learners encounter lexical gaps while reading, the sentence is the primary source of cues that they rely on. The rich contexts were not vague and they increased the predictability of the target words. Also, the subjects do not have to read a full text and remember the information in the previous sentences to figure out the word meaning. Thus, in inference process, they only focus on the target word and the other familiar words in the sentence and they form a connection between the new word and meaning of the sentence. Also, Cetinavci states that the teacher should encourage language learners in guessing process and their linguistic level of thinking on the words should be increased. Based on this point of view, I gave the students an open-ended question. So, the students have a competence in comprehend Identification of the Text (IT), Main Idea (MI) and Supporting Details (SD). When the students are exposed to this learning and guessing process, notable success can be achieved. The teacher also should use this technique in reading teaching.

\section{CONCLUSION}

The implementation of contextual guessing technique in reading comprehension of students of the tenth grade of senior high school can be done effectively. The students can comprehend the text and read the text in contextual guessing technique in front the class. In addition, the students' can promote critical thinking about what they read, give some opportunities to improve their ability through expressing their ideas, or opinions directly, and make the students are more active in teaching reading comprehension. As a result, by implementing contextual guessing technique in teaching reading, the students 
more enthusiastic caused the all of students have big contribution to answering the question. It is supported from the observation sheet. The strength it can be seen that the students can be more fast to comprehend the text without open the dictionary, confident to answer the text, and the students more enthusiastic to read. On other hand, it also improves students motivation and active. The weakness can be seen that the some students lack to understand the material overall because they low vocabulary. It makes the students misunderstanding and the material that the teacher explanations do not complete.

\section{REFERENCES}

Brown, H. D. Language Assessment. Principles and Classroom Practices. New York: Longman. Pearson Education, 2003.

,H. D. Principles of Language Learning and Teaching.. New York: Longman. Pearson Education, 2004.

Çetinavc1, B. M. Contextual Factors in Guessing Word Meaning from Context in a Foreign Language. Procedia - Social and Behavioral Sciences, 116(1999), 2670-2674. https:/ / doi.org/10.1016/j.sbspro.2014.01.633

Clarke, D. F., \& Nation, I. S. P. Guessing the Meanings of Words from Context: Strategy and Techniques. System, 8, 211-220, 1980.

Burners, D. And Page, G. Insight and strategy Teaching Reading, Australia : Harcout Brace Jovanic Group Pty Limited.

Ebrahimi, Z., \& Azhideh, P. The Effects of Teaching Vocabulary Learning Strategies on Iranian EFL Learners 'Vocabulary Development. 3(1), 57-64, 2015.

Gorjian, B., Hayati, A., \& Sheykhiani, M. J. (n.d.). The role of gisting and contextual guessing reading strategies in learners' performance in multiple-choice cloze tests of reading comprehension. 31 .

Grover, J. A Guided to Curriculum Planning in Reading. Wisconsin Department of Public Instruction, 2004.

Grabe, W, and Stoller, F.L. Teaching and Researching Finding. Edinburg: Pearson Education, 2002.

Jalal, S., Rokni1, A., \& Niknaqsh2, H. R. The Effect of Context Clues on EFL Learners' Reading Comprehension. 3(6), 2321-7170, 2013.

Klingner, et al. Teaching Reading Comprehension to Students with Learning Diffuclties. New York: The Guilford Press, 2007.

Kunandar. "Langkah Mudah Penelitian Tindakan Kelas Sebagai Pengembangan Profesi Guru". Jakarta : Rajawali Pers, 2008.

Magdeldin, R., Vocabulary, Y.-G., Youssef, R., Term, S., Exercise, V., \& Page, I. (n.d.). Guessing Vocabulary in Context 1. 1-9.

Martin.V. Reading and Writing to Learn, London. 2008.

Mc Neil, Jhon D. Reading Comprehension. Los Angles: Hopencollins Published, 2000. 
Mikulecky, B S. and Jeffries, L. More Reading Power. Addison Wesley Publishing Company. Inc. Developing teachers.com. Available at: www.developing teachers.com, 1996. Accessed on Saturday, January 02, 2019.

O'Malley, J. Authentic Assesment for English Language Learners. Addition-Wesley Publishing Company, 1996.

Patel et al. Guessing Words-in-Context Strategies Used by Beginning and UpperIntermediate Learners. Unpublished MA dissertation, Bilkent University, Ankara, 2008.

Pearson David, Barbara M. Taylor. Teaching Reading. Laurence Erlbaum Associates. Inc. Publisher. London, 2002.

Qian, T. On Contextual Guessing in Reading Comprehension. US-China Foreign Language. Available at: www.linguist.org , 2005. Accessed on Saturday, January 02, 2019

Rapaport. J. W. What is the 'Context' for Contextual Vocabulary Acquisition? Available at: http://www.cse.buffalo.edu/_rapaport/cva.html, 2000. Accessed on Thursday, January 02, 2019.

Richard, J, John Platt, and Heidi Weber. Longman Dictionary of Applied Linguistics. England: Longman, 2002.

Robert J Tierney \& JohnmE Readence (eds) Reading Strategies and Practices in Teaching reading and Viewing : Quensland Studies Authority. February 2019.

Scott, W.R. Financial Accounting Theory. Second Ed., Prentice Hall International, Inc, 2000.

Smith, Frank. "Understanding Reading a Psycholinguistic Analysis of Reading and Learning to Read", London: Mahwah, 2004.

Sudjana, DR.H. Nana. Cara Belajar Siswa Aktif dalam Proses Belajar Mengajar. Bandung: Sinar Baru Algensido, 1996.

Sugiyono. "Metode Penelitian Pendidikan". Bandung: Alfabeta, 2011. 